\title{
Evaluating the effect of flowering age and forest structure on pollen productivity estimates
}

\author{
Isabelle Matthias • Anne Birgitte Nielsen • \\ Thomas Giesecke
}

Received: 10 March 2012 / Accepted: 20 June 2012/Published online: 10 October 2012

(C) The Author(s) 2012. This article is published with open access at Springerlink.com

\begin{abstract}
Pollen productivity estimates (PPEs) are indispensable prerequisites for quantitative vegetation reconstructions. Estimates from different European regions show a large variability and it is uncertain whether this reflects regional differences in climate and soil or is brought about by different assessments of vegetation abundance. Forests represent a particular problem as they consist of several layers of vegetation and many tree species only start producing pollen after they have attained ages of several decades. Here we used detailed forest inventory data from north-eastern Germany to investigate the effect of flowering age and understory trees on PPEs. Pollen counts were obtained from 49 small to medium sized lakes chosen to represent the different forest types in the region. Surface samples from lakes within a closed forest of Fagus yielded disproportionate amounts of Fagus pollen, increasing its PPE and the variability of all other estimates. These samples were removed from further analysis but indicate a high trunk-space component that is not considered in the Prentice-Sugita pollen dispersal and deposition model. Results of the restricted dataset show
\end{abstract}

Communicated by M.-J. Gaillard.

Electronic supplementary material The online version of this article (doi:10.1007/s00334-012-0373-z) contains supplementary material, which is available to authorized users.

I. Matthias $(\varangle) \cdot$ A. B. Nielsen · T. Giesecke

Department of Palynology and Climate Dynamics,

Albrecht-von-Haller-Institute for Plant Sciences, University of

Göttingen, Untere Karspüle 2, 37073 Göttingen, Germany

e-mail: Isabelle.Matthias@biologie.uni-goettingen.de

A. B. Nielsen

Department of Geology, University of Lund, Sölvegatan 12, 223

62 Lund, Sweden important differences in PPEs based on the consideration of flowering age and understory position. The effect is largest for slow growing and/or late flowering trees like Fagus and Carpinus while it is minimal for species that flower early in their development like Betula and Alnus. The large relevant source area of pollen (RSAP) of $7 \mathrm{~km}$ obtained in this study is consistent with the landscape structure of the region.

Keywords Germany - Relevant source area of pollen . Pollen productivity estimates - Forest structure . Flowering age $\cdot$ Surface samples

\section{Introduction}

It is an old dream of quaternary palynologists to translate pollen diagrams into quantitative representations of past plant abundance (Davis 2000). This is especially important where pollen analytical results are used by neighboring disciplines like archeology (Gaillard 2007) and vegetation or climate modeling (Miller et al. 2008; Gaillard et al. 2010). Also the influence of land use and abiotic factors on regional vegetation patterns can only be evaluated if it is possible to reduce the effect of differential pollen production and dispersal in vegetation reconstructions (Nielsen et al. 2012). Studies investigating the pollen vegetation relationship have been conducted for several decades and the concept of finding factors for correcting pollen proportions to reflect the vegetation abundance goes back to Davis (1963). However, the non-linearity between pollen and vegetation proportions hampered the application of simple correction factors. The development of the extended $\mathrm{R}$-value (ERV) model was intended to correct for the nonlinearity, and allow the estimation of the relative pollen 
productivity of different species (Parsons and Prentice 1981; Prentice and Parsons 1983). This approach was combined with knowledge from studies on pollen transport (e.g. Tauber 1965) to develop numerical models that separate the two species-specific components: pollen production and pollen dispersal (Prentice 1985; Sugita 1993, 1994). Using these models, the dispersal and deposition of pollen can be simulated based on the different fall speed of differently shaped pollen types, which can be estimated or measured directly (Eisenhut 1961), provided estimates of relative pollen productivity are available. Over the last decade, continued theoretical development has led to a conceptual framework that realizes the longstanding dream of quantitative vegetation reconstructions (Sugita 2007a, b; Gaillard et al. 2008). Together with the development of user-friendly computer programs (Sugita 2007a, b; Bunting and Middleton 2005), this has given the impulse for many palynologists to work towards quantitative reconstructions. As mentioned before, pollen productivity estimates (PPEs) are a very important component of these models, but estimating the relative (or absolute) production of pollen of different plant species remains a challenge, as many different factors influence the results (Broström et al. 2008). Moreover, each study addressing the pollen-vegetation relationship to obtain PPEs provides new information to test the models and theoretical concepts of pollen transport and deposition, highlighting potential factors influencing the calculation of PPEs and adding confidence to future reconstructions. Recently a number of these studies have been carried out in Europe: e.g. Norway (Hjelle 1998), Sweden (Sugita et al. 1999; Broström et al. 2004; Von Stedingk et al. 2008), Denmark (Nielsen 2004), England (Bunting et al. 2005), Finland (Räsänen et al. 2007), Estonia (Poska et al. 2011), northern Germany (Theuerkauf et al. 2012), and the Czech Republic (Abraham and Kozáková 2012) as well as for the Swiss Jura (Mazier et al. 2008) and the Swiss Plateau (Soepboer et al. 2007). Initial comparisons of different regional studies revealed large differences in estimated PPEs, which may be due to real differences in pollen production, brought about by regionally different climate or soils, but could also stem from methodological differences (Broström et al. 2008). The influence of vegetation survey methods on PPEs have been shown on the small scale for heathland vegetation in Norway (Bunting and Hjelle 2010), but have so far not been investigated for different assessments of forest vegetation on a landscape scale.

Forests are multi-layered and trees require a number of years of growth before they start to produce flowers and shed pollen. While the former factor will influence the assessment of vegetation cover, the latter affects the vegetation-pollen relationship directly. For example, a 15-year-old plantation of Pinus will hardly be the source of much Pinus pollen, while it will appear like a dense forest on an aerial photograph or satellite image. Even when a vegetation survey is conducted on the ground, it is difficult to decide whether or not a Fagus tree has reached flowering age.

The forest inventory data in north-eastern Germany are exceptionally detailed and thus permit the assessment of the influence of flowering age and canopy structure on PPEs. Moreover, as the data are available in digitized formats there is little limitation to the area that can be used in the analysis.

The aim of this study is: (i) to contribute to the emerging dataset on regional relative PPEs with a focus on tree species; (ii) to examine what influence flowering age and understory position have on PPEs of the major tree species.

\section{Material and methods}

\section{Study area}

For this study we have chosen the state of Brandenburg in the eastern part of Germany, because it has a large number of lakes and different forest types (Fig. 1) for which detailed inventory data are available. The maximum limit of the Scandinavian ice sheet runs through Brandenburg in a NW to SE direction and this study was confined to the glaciated part with abundant lakes. The area is characterized by series of ground and terminal moraines and outwash plains with different soil substrates (Liedtke and Marcinek 2002). Climatically, Brandenburg is situated between the oceanic climate of Western Europe and the continental climate further east. Precipitation ranges between 450 and $720 \mathrm{~mm}$, with the driest areas in the southeast (Linke et al. 2010). The state of Brandenburg has a forest cover of $37 \%$ (1.09 million ha) of which pine forests constitute $70 \%$ and mixed forests about $11 \%$ (Engel 2010). The agriculturally used area represents $45 \%$ (1.32 million ha) consisting of $78.3 \%$ arable land and $21.3 \%$ pastures (MLUV 2009).

Sample collection and preparation

The depositional environment has an influence on the pollen composition (Giesecke and Fontana 2008; Pardoe et al. 2010) and when studying the pollen-vegetation relationship it is therefore important to standardize the size and type of sampling site as much as possible to reduce this variability. We aimed at sampling small lakes with a single, simple basin with as small a peat margin as possible and without permanent inflow. Lakes that were deeper in proportion to the lake size were preferred, to avoid lakes with a high sediment redeposition (Giesecke and Fontana 2008). The estimation of pollen productivity requires samples from sites situated within different vegetation 




Fig. 1 Vegetation map of Brandenburg, based on CORINE Land Cover 2000 (Umweltbundesamt, DLR-DFD 2004) with the study sites. Inset: map of Europe showing the state of Brandenburg, where the study area is situated

types so that abundance gradients for different taxa can be obtained. In order to achieve this, the constraint of uniform lake size had to be relaxed. Potential lakes were selected from topographical maps, aerial and satellite photographs and their suitability was assessed in the field. In this way a total of 49 lakes ranging between 0.5 and 32 ha were selected and sampled (Table 1).

Sampling was carried out during the spring and summer of 2009 using a HON-Kajak sediment corer (Renberg 1991) with a $10 \mathrm{~cm}$ diameter. The short cores obtained were sampled in the field at $1 \mathrm{~cm}$ intervals beginning at the sediment water interface (or shortly above it where the interface was diffuse). Samples were stored in small plastic bags at $4{ }^{\circ} \mathrm{C}$ until processing.

In the lab a subsample of $1 \mathrm{~cm}^{3}$ was taken from the uppermost sample of each short core using a syringe. In a few cases from cores with a diffuse sediment-water interface this sample yielded a very low pollen concentration and here the second sample in the short core was also subsampled and processed. The subsamples were processed for pollen analysis following the general procedure described by Bennett and Willis (2001), without sieving and using a 2 min acetolysis. The sample residues were mounted in glycerol and counted at $400 \times$ magnification, while cereals were identified at $1,000 \times$ magnification. The pollen was identified using the keys of Beug (2004) and Moore et al. (1991), and the reference collection of the Department of Palynology and Climate Dynamics, Göttingen University. A minimum of 1,000 terrestrial pollen grains were counted in each sample. The pollen sum is defined as the sum of all terrestrial pollen grains.

\section{Vegetation data}

Detailed inventories of East German forests started before the 1940s and intensified during the 1960s and 70s. Much of this information has been continually updated and later digitized and collected in forest inventory databases. The states of Brandenburg, Mecklenburg-Vorpommern and Thuringia have collected this information with a standardized format in the database "Datenspeicher Wald" (DSW2; http://www.dsw2.de/index.html). Most of the forest inventory data for Brandenburg and adjacent parts of Mecklenburg-Vorpommern may be obtained from this database. However, large parts of the forest in Brandenburg are owned by the German Federation and partly administered by a federal agency "Bundesanstalt für Immobilienaufgaben", who provided the same type of forest inventory data for the immediate study area. For each forest stand, the inventory data contain information on the absolute tree cover, age, and wood volume as well as forest structure differentiated into several layers e.g. superstructure, rejuvenation, understory. These layers were classified into two stories, canopy, and understory. Unlike a bird's-eye view, as obtained from aerial and satellite images the database yields information on the total ground cover of individual species (Fig. 2). Information about the cover on different types of non-forested vegetation was derived from the biotope and land-use mapping project (CIR-Biotop- und Landnutzungstypenkartierung download: http://www.mugv.brandenburg.de/cms/detail.php/bb2.c. 515599.de, 2009 version, accessed 1 December 2010). This map was constructed in 1991-1996 and is updated annually. The map was reclassified and generalized so that the resulting units would represent unique combinations of plants that were considered in the PPE calculations. The area of arable fields was assigned to a mixture of crops according to information of yield for the year 2009 (MLUV 2009), assuming an even distribution of cultivation of the different crops in Brandenburg.

All spatial data were combined and handled in ArcGIS 9 (ESRI) and Excel (Microsoft), and the vegetation cover data within a radius of $15 \mathrm{~km}$ around each sampling site was extracted in four different ways: 


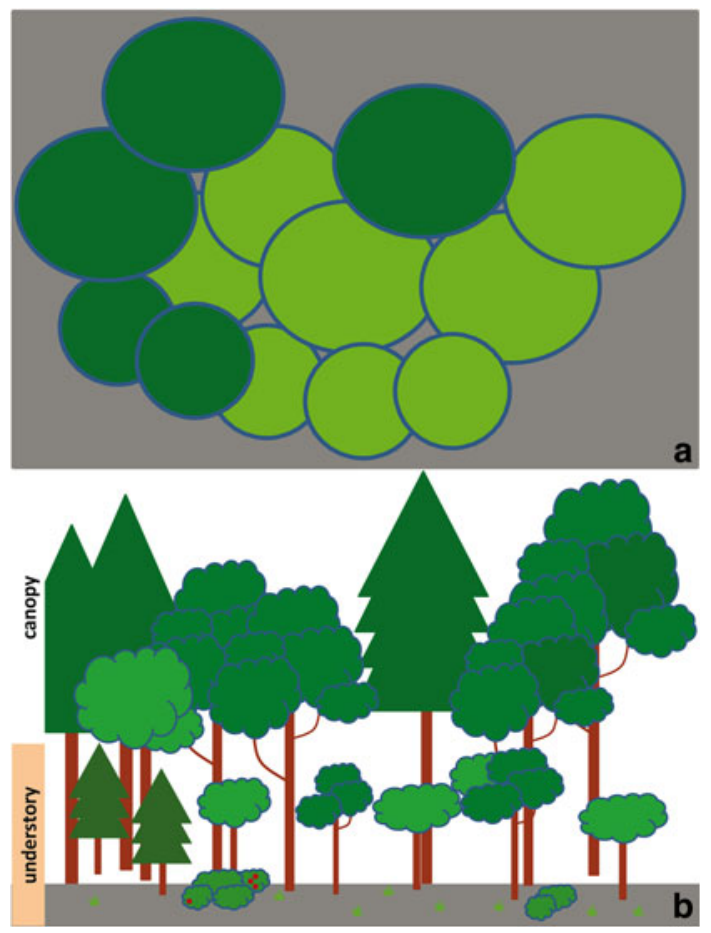

Fig. 2 a Example of a forest canopy from above, which is the basis for estimates of tree abundance from aerial photographs and satellite images; $\mathbf{b}$ a simplification of canopy layers as recognized in the forest inventory data illustrating the classification in canopy and understory that was used here

1. All forest inventory data were included (allFID).

2. Forest data were included if the flowering age of the different trees and shrubs had been reached (allFIDage).

3. Only data from the canopy layer were included, while information on understory trees was excluded (canopyFID).

4. Only data from the canopy layer were included, and only if the flowering age of the different taxa was reached (canopyFIDage). The information on the flowering age for the trees was obtained from the literature (Table 2).

\section{ERV analysis}

The four different sets of assembled vegetation information for a radius of $15 \mathrm{~km}$ around the lakes were compared to pollen percentages in the surface samples. For distance weighting, vegetation data was compiled in $250 \mathrm{~m}$-wide rings for the first $\mathrm{km}$ and one $\mathrm{km}$-wide rings from 1 to $15 \mathrm{~km}$ distance from the center of the lake. To evaluate the effect of ring width on the results we compiled one test set with $200 \mathrm{~m}$ rings over the first $3 \mathrm{~km}$. Calculations of PPEs and the relevant source area of pollen (RSAP) were conducted using the Program ERV-Analysis 1.2.3 (Sugita unpublished). Each of the three different ERV submodels
(Prentice and Parsons 1983; Sugita 1994) were applied using the Ring Source model (Sugita et al. 1999) to distanceweight the vegetation data. Wind speed was set to $3 \mathrm{~m} / \mathrm{sec}$ and pollen fall speeds were taken from the literature or estimated (Table 2). Lake radii were set to an average radius of $140 \mathrm{~m}$ (Nielsen and Sugita 2005; Soepboer et al. 2007). We used Pinus as a reference taxon as it is abundant in the vegetation and pollen samples from all sites and represents mainly the single native species, Pinus sylvestris. Initial analysis of the full dataset showed that model performance was improved by reducing the samples to a subset of 39 lakes, omitting lakes where Fagus exceeded a cover of 5 ha within a radius of $250 \mathrm{~m}$ from the center of the lake.

We calculated PPEs for 16 taxa (Table 2), of which one is a group of taxa. This group is labeled "wild herbs" and consists of the uncultivated terrestrial herb pollen, including e.g. Poaceae, Plantago lanceolata, Rumex acetosa, $R$. acetosella, and Chenopodiaceae, with Poaceae being the most abundant. The fall speed for the wild herbs was estimated, using the fall speed of the most frequent taxa in this group.

\section{Results}

All of the lakes sampled are surrounded by at least some trees and most are adjacent to or within closed canopy forest, as this is where most detailed vegetation information is available. This close proximity of the lakes to forested land explains the high tree pollen proportions of up to $95 \%$ in the surface samples. It is noteworthy that the amount of tree pollen is above $75 \%$ in all samples, even though the overall tree cover in the state of Brandenburg is only $37 \%$. The pollen diagram (Fig. 3) presents all 49 sampled lakes along a north-south gradient, illustrating the regional distribution limit of Fagus. Regardless of the extra-local abundance of Fagus in the region, lakes where the tree dominates the shore of the lake were found to stand out in their abundance of Fagus pollen (Fig. 4) and were therefore omitted from further analysis. The restricted dataset contains a good dispersion of pollen abundance for the following taxa: Alnus (4-37\%), Betula (6-24\%), Fagus (0.2-12\%), Pinus (17-58 \%), Quercus (3-19\%), and the wild herbs (3-18\%). Although a maximum of $19 \%$ Carpinus pollen is represented in one sample, the pollen type is restricted to few samples. Also pollen of Fraxinus (0-4\%), Populus (0-1\%), and Tilia cordata (0-2\%) only occurs in a small number of samples, while Picea (0-4\%) as well as the cereal pollen types occur in many samples with low abundances.

\section{RSAP}

For all three ERV submodels, likelihood function scores decrease to a distance of $7 \mathrm{~km}$ from the center of the lakes 
Table 1 Characteristics of the study sites

\begin{tabular}{|c|c|c|c|c|c|c|}
\hline No. & Name & $\begin{array}{l}\text { Latitude } \\
\text { (decimal degrees) }\end{array}$ & $\begin{array}{l}\text { Longitude } \\
\text { (decimal degrees) }\end{array}$ & Size (ha) & Radius (m) & Depth (m) \\
\hline 1 & Steinsee & 53.31843 & 13.6226 & 6.7 & 146 & 3.5 \\
\hline 2 & Petznicksee & 53.31551 & 13.6093 & 13.1 & 204 & 7.3 \\
\hline 3 & Kleiner Petznicksee & 53.31142 & 13.6018 & 5.1 & 127 & 2 \\
\hline 4 & Hausseebruch* & 53.24517 & 13.5306 & 3 & 98 & 10.1 \\
\hline 5 & Tiefer See & 53.23517 & 13.3631 & 17.2 & 234 & 33.7 \\
\hline 6 & Tiefer Clöwen* & 53.23330 & 13.5311 & 8.5 & 165 & 10.3 \\
\hline 7 & Poviestsee & 53.22387 & 13.5124 & 22 & 265 & 11.7 \\
\hline 8 & Kleiner Rathsburgsee* & 53.20058 & 13.9394 & 3.2 & 101 & 6.6 \\
\hline 9 & Kleiner Lychensee & 53.19640 & 13.2704 & 8.5 & 165 & 13.7 \\
\hline 10 & Bugsee* & 53.19298 & 13.9100 & 1.5 & 69 & 6 \\
\hline 11 & Kleiner Trinsee & 53.15804 & 13.8674 & 1.1 & 59 & 5.6 \\
\hline 12 & Kleiner Zermittensee & 53.14401 & 12.8227 & 5.8 & 136 & 7.3 \\
\hline 13 & Aalgastsee* & 53.13914 & 13.9050 & 0.8 & 51 & 3.3 \\
\hline 14 & Weißesee & 53.13679 & 13.1089 & 5.8 & 136 & 8.2 \\
\hline 15 & Glabatzsee* & 53.13607 & 12.9745 & 2 & 80 & 7.3 \\
\hline 16 & Temnitzsee & 53.12171 & 13.6462 & 9.9 & 178 & 6.7 \\
\hline 17 & Plötzensee & 53.11484 & 12.9704 & 5.7 & 135 & 8.8 \\
\hline 18 & Kleiner Gollinsee & 53.02887 & 13.5882 & 3.2 & 101 & 3.3 \\
\hline 19 & Teufelssee* & 53.01995 & 12.8263 & 4.8 & 124 & 12 \\
\hline 20 & Heiliger See & 53.01560 & 13.8720 & 9.1 & 170 & 10.8 \\
\hline 21 & Dovinsee & 52.99795 & 13.7881 & 20.8 & 257 & 7 \\
\hline 22 & Schwarzersee* & 52.99400 & 13.9030 & 3.3 & 103 & 4.7 \\
\hline 23 & Kleiner Plunzsee & 52.99271 & 13.9359 & 2.8 & 94 & 3.8 \\
\hline 24 & Runder Köllnsee & 52.98064 & 13.6685 & 2.7 & 93 & 3.9 \\
\hline 25 & Papensee & 52.91403 & 13.2390 & 5.9 & 137 & 8.3 \\
\hline 26 & Buckowsee & 52.81319 & 13.6087 & 13.8 & 210 & 8.8 \\
\hline 27 & Schiebelsee & 52.74569 & 14.0463 & 0.5 & 40 & 4.1 \\
\hline 28 & Sonnenburger Fenn & 52.74459 & 14.0419 & 2.3 & 86 & 3.5 \\
\hline 29 & Baasee* & 52.74333 & 14.0258 & 2.2 & 84 & 3.6 \\
\hline 30 & Röthsee & 52.69485 & 13.9429 & 3.3 & 103 & 2.7 \\
\hline 31 & Modderpfuhl & 52.67960 & 13.9084 & 1.7 & 74 & 3.8 \\
\hline 32 & Sternebecker See & 52.67933 & 14.0025 & 7.7 & 157 & 10.8 \\
\hline 33 & Piechesee & 52.65964 & 13.9211 & 4.5 & 120 & 3 \\
\hline 34 & Blumenthalsee & 52.65168 & 13.9272 & 8.4 & 164 & 4.2 \\
\hline 35 & Staffsee & 52.59436 & 14.1890 & 9.6 & 175 & 3.8 \\
\hline 36 & Kleiner Tornowsee & 52.57950 & 14.0930 & 3.8 & 110 & 10 \\
\hline 37 & Schwarzer See & 52.55541 & 14.0835 & 7.1 & 150 & 4.3 \\
\hline 38 & Kesselsee & 52.52920 & 14.0796 & 2.7 & 93 & 7.8 \\
\hline 39 & Kessel See & 52.41206 & 14.3562 & 3.5 & 106 & 1.2 \\
\hline 40 & Karbuschsee & 52.18666 & 13.6543 & 12.2 & 197 & 17.5 \\
\hline 41 & Kleiner Treppelsee* & 52.13257 & 14.4585 & 5.4 & 131 & 4.5 \\
\hline 42 & Ziskensee & 52.10599 & 14.4699 & 2.6 & 91 & 4.4 \\
\hline 43 & Klautzkesee & 52.09969 & 14.5223 & 6.4 & 143 & 1.8 \\
\hline 44 & Rähdensee & 52.07074 & 14.4465 & 11.8 & 194 & 6.3 \\
\hline 45 & Buchwaldsee & 52.02388 & 14.6300 & 1.9 & 78 & 2.3 \\
\hline 46 & Kleinsee & 51.94195 & 14.5101 & 14 & 211 & 2 \\
\hline 47 & Großsee & 51.93298 & 14.4719 & 31.7 & 318 & 8.3 \\
\hline 48 & Deulowitzer See & 51.92377 & 14.6467 & 13.9 & 210 & 4 \\
\hline 49 & Teersee & 51.91930 & 14.2263 & 8 & 160 & 3.7 \\
\hline
\end{tabular}

* Lakes with more than 5 ha Fagus within a radius of $250 \mathrm{~m}$ from the lake centre, omitted from the restricted dataset 
Table 2 Pollen fall speed of 16 taxa and the flowering age considered for the tree taxa

\begin{tabular}{|c|c|c|c|}
\hline Pollen taxa & $\begin{array}{l}\text { Fall } \\
\text { speed } \\
(\mathrm{m} / \mathrm{s})\end{array}$ & Tree taxa & $\begin{array}{l}\text { Flowering } \\
\text { age }\end{array}$ \\
\hline Alnus & $0.021^{\mathrm{a}}$ & Alnus glutinosa & $10^{\mathrm{d}}$ \\
\hline Betula & $0.022^{\mathrm{a}}$ & $\begin{array}{l}\text { Betula } \\
\quad \text { pendula }\end{array}$ & $10^{\mathrm{d}}$ \\
\hline Carpinus & $0.042^{\mathrm{a}}$ & $\begin{array}{r}\text { Carpinus } \\
\text { betulus }\end{array}$ & $30^{\mathrm{d}}$ \\
\hline Fagus & $0.057^{\mathrm{b}}$ & $\begin{array}{l}\text { Fagus } \\
\quad \text { sylvatica }\end{array}$ & $50^{\mathrm{d}}$ \\
\hline Fraxinus & $0.022^{\mathrm{a}}$ & $\begin{array}{l}\text { Fraxinus } \\
\text { excelsior }\end{array}$ & $30^{\mathrm{d}}$ \\
\hline $\begin{array}{l}\text { Larix } \\
\quad(\text { and Pseudotsuga) }\end{array}$ & $0.126^{\mathrm{a}}$ & Larix & $10^{\mathrm{e}}$ \\
\hline Picea & $0.056^{\mathrm{a}}$ & Picea & $40^{\mathrm{f}}$ \\
\hline Pinus & $0.031^{\mathrm{a}}$ & Pinus & $20^{\mathrm{f}, \mathrm{g} * *}$ \\
\hline Populus & $0.025^{\mathrm{a}}$ & Populus alba & $20^{\mathrm{d}}$ \\
\hline Quercus & $0.035^{\mathrm{a}}$ & Pseudotsuga & $30^{\mathrm{h}}$ \\
\hline Tilia & $0.032^{\mathrm{a}}$ & Quercus robur & $30^{\mathrm{d}}$ \\
\hline Avena-type & $0.078^{\mathrm{c}}$ & Tilia cordata & $20^{\mathrm{e}}$ \\
\hline Hordeum-type & $0.06^{*}$ & & \\
\hline Secale & $0.06^{\mathrm{b}}$ & & \\
\hline Triticum-type & $0.078^{\mathrm{c}}$ & & \\
\hline wild herbs & $0.03425^{*}$ & & \\
\hline
\end{tabular}

${ }^{a}$ Eisenhut (1961)

b Gregory (1973)

c Cerealia in Soepboer et al. 2007

d Schütt et al. (2006)

e Haller and Fickler (1955)

f Rispens (2003)

g Schröck (1949)

h Stinglwagner et al. (2005)

* Estimated fall speed, ** average value

(Fig. 5). Scores for submodel 3 show a small dip at this distance, while submodels 1 and 2 have reached the asymptote at this point. While Fig. 5 is based on the inclusion of all trees that have reached their flowering age, the results for the different datasets yield similar trends indicating the RSAP at $7 \mathrm{~km}$ from the centers of the lakes. We tested if this result for the RSAP was influenced by compiling the vegetation data over $1 \mathrm{~km}$ wide rings, but did not find narrower rings to have any influence on the result.

Pollen-vegetation relationships

Scatter-plots depicting the ERV-model adjusted pollenvegetation relationships (Fig. 6) give some indication of the reliability of calculated PPEs. The patterns of points around the regression line differ little between the four sets of forest inventory data and therefore only the results based on the dataset allFIDage are shown for the three ERV submodels. As with the likelihood function scores, the patterns are most similar between ERV submodels 1 and 2 . The patterns differ most between the three submodels for the wild herbs with a particularly poor fit for model 3, whereas Pinus shows the best fit with this submodel. Most of the more abundant tree species have long gradients and positive relationships between pollen and vegetation data. The trend is especially clear for the reference taxon Pinus, but also Alnus, Carpinus, Fraxinus, Larix/Pseudotsuga, and Quercus show similarly good fits for all ERV submodels. The pollen-vegetation relationship for Carpinus and Fraxinus is captured by few samples while the trend for Tilia cordata is dominated by the elevated pollen and plant abundance at a single lake. The pollen-vegetation relationship is weak for Betula, Picea, and Populus and poor for most cereals and wild herbs.

\section{Vegetation cover}

When sampling the lakes, the vegetation immediately around each lake was noted in the field and for random sites later compared with the information from the forest inventory data. There was a good agreement, often down to small patches or groups of trees. In effect considering only those trees that have reached flowering age, or that occur in the canopy, means reducing the amount of vegetation cover. This is shown in Table 3 for tree species within $7 \mathrm{~km}$ around the lakes (the RSAP). Pinus dominates the area around the sampled lakes with an average cover of about $30 \%$ (Table 3), but with a high variability between the different lakes, as indicated by a standard deviation (s.d.) of more than $50 \%$. Pinus cover is little affected by omitting trees below average flowering age or those occurring in the understory. The next most abundant trees are Fagus and Quercus, covering on average 6 and $4 \%$ of the RSAP, respectively. Their abundance is much affected by omitting trees below flowering age and Fagus is especially reduced when removing the understory trees. Betula, Picea, and Larix/Pseudotsuga have average abundances of about $2 \%$. While none of these constraints greatly affected Betula, the constraint of flowering age reduces the abundance of Picea and, to a lesser extent, Larix/Pseudotsuga. Alnus, which is often found at the shore of the sampled lakes only reaches an average cover of $0.9 \%$ and age or canopy structure, have almost no influence. Carpinus, Fraxinus, Populus, and Tilia cordata occur on average with less than $1 \%$ cover and the removal of their understory occurrences reduces the abundance of Carpinus and T. cordata by half, while Populus is not affected at all. 


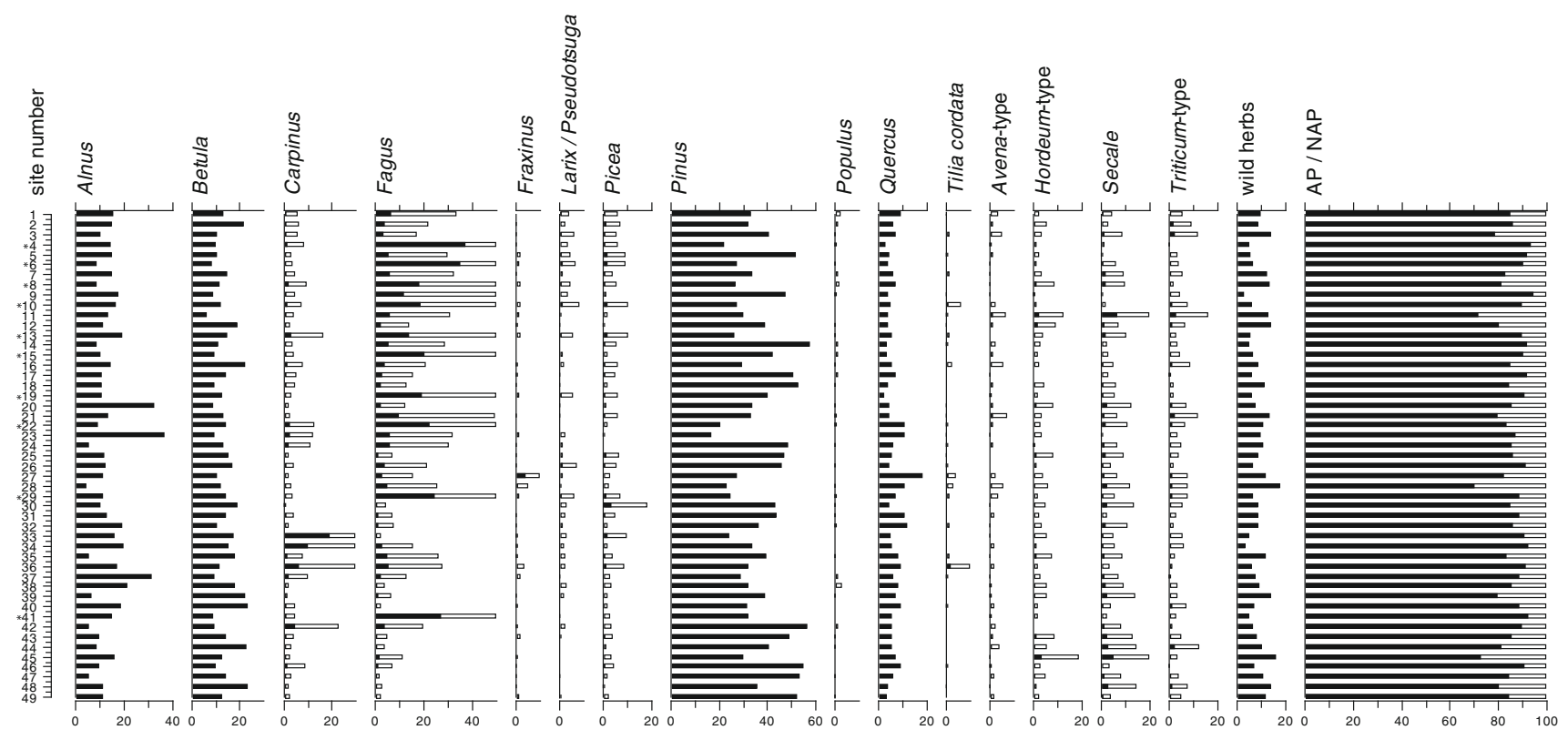

Fig. 3 Percentage pollen diagram of selected types for all surface samples, based on the sum of all terrestrial pollen. The samples are ordered from north to south; $\times 5$ exaggeration is indicated by hollow bars. Asterisks mark the omitted lakes

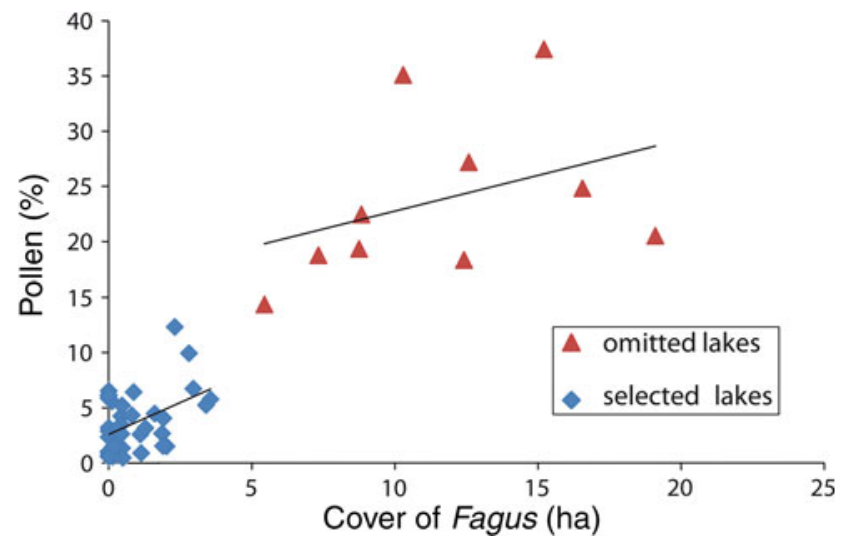

Fig. 4 Scatter-plot of the cover of Fagus trees (ha) within a radius of $250 \mathrm{~m}$ from the lake center vs. the percentage of Fagus pollen in the surface samples of all study sites. Trend-lines are linear regressions for the two sets. Lakes within closed Fagus forests yielded disproportionately higher amounts of Fagus pollen and were therefore excluded from further analysis

\section{Reference taxon and the representation of herb pollen}

As calculation of absolute PPEs on a landscape scale is difficult and requires pollen accumulation rates (Sugita et al. 2010), PPEs are commonly estimated relative to a reference taxon, which needs to be present in the pollen count and vegetation of all samples. A common choice is Poaceae (Broström et al. 2008) as it occurs almost everywhere. Here forest lakes were targeted and the cover of herbaceous vegetation on the forest floor was not assessed. Consequently, vegetation information on Poaceae is incomplete, and probably particularly biased near the lakes.

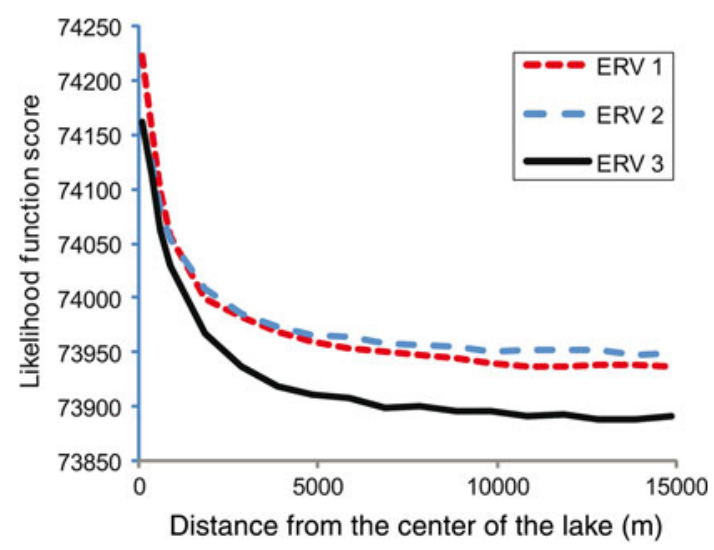

Fig. 5 Likelihood function scores for the ERV submodels 1, 2 and 3, based on the restricted dataset of 39 lakes with an assumed radius of $140 \mathrm{~m}$, considering all trees that have reached their respective flowering age (allFIDage)

Poaceae was therefore not chosen as a reference taxon and not calculated separately (but combined with the other wild herbs in an attempt to minimize this bias). The scatter-plots in Fig. 6 show a poor fit for herbaceous pollen which may reflect the sampling design, where lakes seldom border non-forested areas. As the commonest tree in the study region, Pinus fulfilled all requirements of a reference taxon including a good fit between vegetation and pollen data.

\section{PPEs}

Taxa that show good fits in the scatter-plots (Fig. 6) also yield similar PPEs in the different ERV submodels 


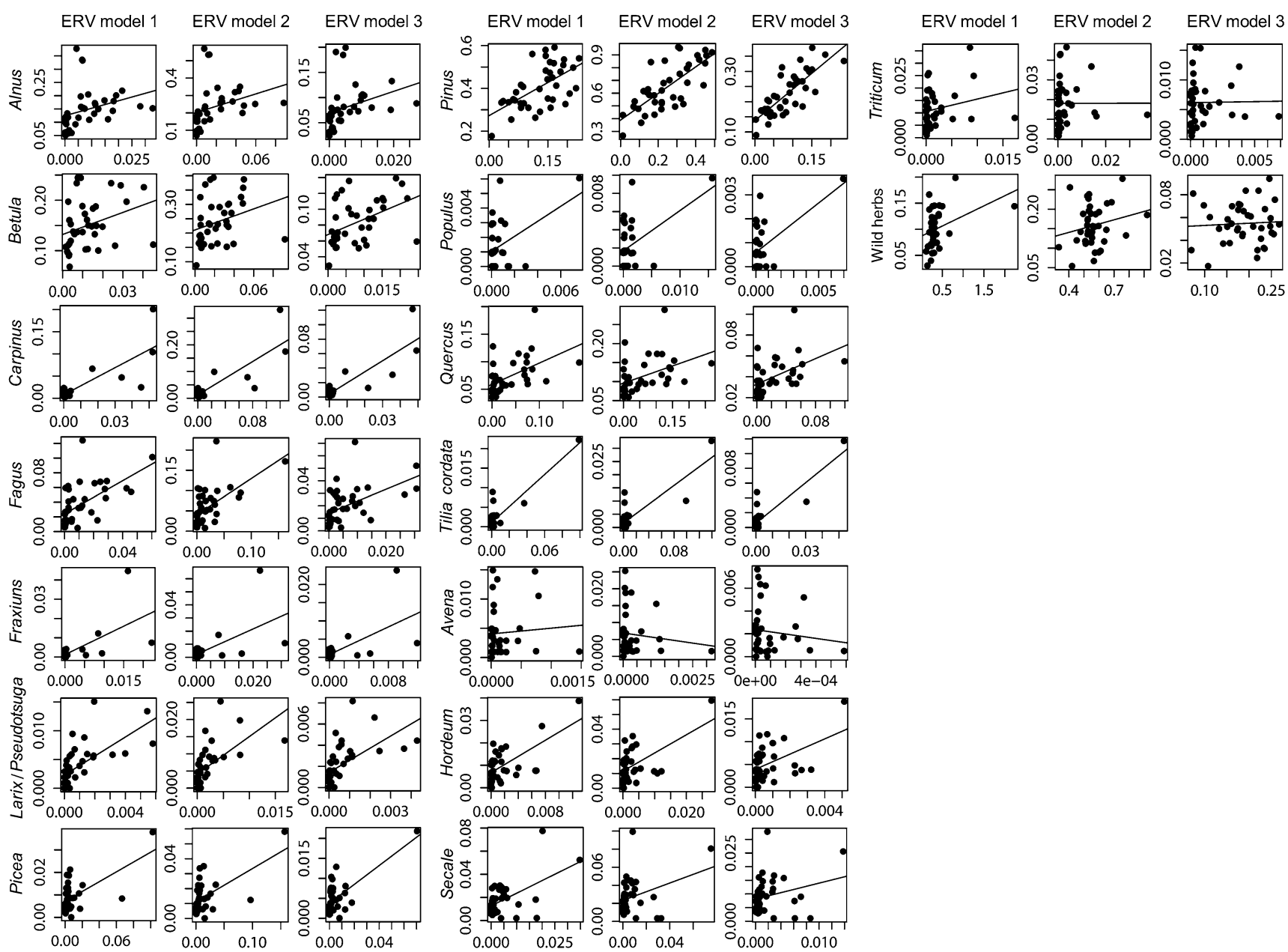

Fig. 6 Scatter-plots of pollen ( $y$-axis) and vegetation ( $x$-axis) data reached (allFIDage). ERV 1 adjusted vegetation proportion vs. pollen of the 16 selected taxa within the RSAP, based on the dataset proportion. ERV 2 vegetation proportion vs. adjusted pollen proportion. ERV 3 relative pollen loading vs. absolute vegetation

Table 3 Average cover and s.d. (\%) of the tree taxa within the RSAP

\begin{tabular}{|c|c|c|c|c|}
\hline & $\begin{array}{l}\text { allFID } \\
\text { cover } \pm \text { s.d. }\end{array}$ & $\begin{array}{l}\text { allFIDage } \\
\text { cover } \pm \text { s.d. }\end{array}$ & $\begin{array}{l}\text { canopyFID } \\
\text { cover } \pm \text { s.d. }\end{array}$ & $\begin{array}{l}\text { canopyFIDage } \\
\text { cover } \pm \text { s.d. }\end{array}$ \\
\hline Alnus & $0.85 \pm 0.71$ & $0.85 \pm 0.71$ & $0.84 \pm 0.71$ & $0.83 \pm 0.69$ \\
\hline Betula & $2.07 \pm 1.11$ & $2.05 \pm 1.10$ & $1.92 \pm 1.00$ & $1.89 \pm 0.99$ \\
\hline Carpinus & $0.74 \pm 0.91$ & $0.64 \pm 0.89$ & $0.34 \pm 0.53$ & $0.33 \pm 0.53$ \\
\hline Fagus & $6.36 \pm 5.61$ & $4.23 \pm 4.34$ & $2.77 \pm 2.75$ & $2.55 \pm 2.55$ \\
\hline Fraxinus & $0.13 \pm 0.14$ & $0.10 \pm 0.13$ & $0.10 \pm 0.12$ & $0.09 \pm 0.11$ \\
\hline Larix and Pseudotsuga & $2.21 \pm 1.31$ & $1.84 \pm 1.19$ & $1.98 \pm 1.24$ & $1.77 \pm 1.17$ \\
\hline Picea & $2.32 \pm 1.79$ & $1.55 \pm 1.22$ & $1.89 \pm 1.47$ & $1.26 \pm 1.04$ \\
\hline Pinus & $33.61 \pm 17.79$ & $32.43 \pm 16.87$ & $33.08 \pm 17.25$ & $32.04 \pm 16.57$ \\
\hline Populus & $0.18 \pm 0.17$ & $0.17 \pm 0.17$ & $0.18 \pm 0.17$ & $0.17 \pm 0.17$ \\
\hline Quercus & $4.36 \pm 2.76$ & $3.01 \pm 2.08$ & $2.89 \pm 1.93$ & $2.49 \pm 1.84$ \\
\hline Tilia cordata & $0.39 \pm 0.27$ & $0.25 \pm 0.27$ & $0.16 \pm 0.15$ & $0.14 \pm 0.15$ \\
\hline
\end{tabular}

(Table 4). The PPEs were taken at the RSAP $(7 \mathrm{~km})$ and vary especially for Alnus, Populus and all non-arboreal pollen types between different submodels. The four datasets with differently assessed tree-cover abundance based on flowering age and forest structure affect the PPEs in different directions. Most strongly affected is Carpinus, 
Table 4 Pollen productivity estimates ( \pm s.d.); calculated with the lake dispersal model (Prentice-Sugita-model: Sugita et al. 1999), wind speed of $3 \mathrm{~m} / \mathrm{s}$ and Pinus as reference taxon

\begin{tabular}{|c|c|c|c|c|c|}
\hline Taxon & $\begin{array}{l}\text { ERV } \\
\text { submodel }\end{array}$ & $\begin{array}{l}\text { allFID } \\
P P E \pm \text { s.d. }\end{array}$ & $\begin{array}{l}\text { allFIDage } \\
\text { PPE } \pm \text { s.d. }\end{array}$ & $\begin{array}{l}\text { canopyFID } \\
\text { PPE } \pm \text { s.d. }\end{array}$ & $\begin{array}{l}\text { canopyFIDage } \\
\mathrm{PPE} \pm \text { s.d. }\end{array}$ \\
\hline Alnus & $\begin{array}{l}\text { ERV } 1 \\
\text { ERV } 2 \\
\text { ERV } 3\end{array}$ & $\begin{array}{l}4.55 \pm 2.29 \\
2.64 \pm 0.26 \\
2.69 \pm 0.31\end{array}$ & $\begin{array}{l}3.83 \pm 1.19 \\
2.25 \pm 0.23 \\
2.74 \pm 0.22\end{array}$ & $\begin{array}{l}4.75 \pm 0.99 \\
2.65 \pm 0.17 \\
3.42 \pm 0.27\end{array}$ & $\begin{array}{l}4.78 \pm 0.83 \\
2.5 \pm 0.25 \\
2.73 \pm 0.29\end{array}$ \\
\hline Betula & $\begin{array}{l}\text { ERV } 1 \\
\text { ERV } 2 \\
\text { ERV } 3 \\
\end{array}$ & $\begin{array}{l}2.34 \pm 1.78 \\
1.62 \pm 0.61 \\
2.35 \pm 0.31\end{array}$ & $\begin{array}{l}1.56 \pm 1.08 \\
1.4 \pm 0.59 \\
1.7 \pm 0.34\end{array}$ & $\begin{array}{l}2.17 \pm 0.75 \\
1.26 \pm 0.58 \\
2.37 \pm 0.34\end{array}$ & $\begin{array}{l}1.9 \pm 0.73 \\
1.72 \pm 0.43 \\
2.24 \pm 0.3\end{array}$ \\
\hline Carpinus & $\begin{array}{l}\text { ERV } 1 \\
\text { ERV } 2 \\
\text { ERV } 3\end{array}$ & $\begin{array}{l}1.94 \pm 0.16 \\
1.75 \pm 0.07 \\
1.56 \pm 0.03\end{array}$ & $\begin{array}{l}1.89 \pm 0.17 \\
1.52 \pm 0.07 \\
1.67 \pm 0.09\end{array}$ & $\begin{array}{l}3.14 \pm 0.24 \\
2.5 \pm 0.11 \\
3.2 \pm 0.11\end{array}$ & $\begin{array}{l}3.46 \pm 0.31 \\
2.61 \pm 0.1 \\
2.94 \pm 0.13\end{array}$ \\
\hline Fagus & $\begin{array}{l}\text { ERV } 1 \\
\text { ERV } 2 \\
\text { ERV } 3\end{array}$ & $\begin{array}{l}1.08 \pm 0.08 \\
0.93 \pm 0.04 \\
1.07 \pm 0.05\end{array}$ & $\begin{array}{l}1.33 \pm 0.12 \\
1.01 \pm 0.04 \\
1.03 \pm 0.08\end{array}$ & $\begin{array}{l}1.8 \pm 0.19 \\
1.64 \pm 0.06 \\
1.67 \pm 0.15\end{array}$ & $\begin{array}{l}1.91 \pm 0.23 \\
1.39 \pm 0.1 \\
1.76 \pm 0.11\end{array}$ \\
\hline Fraxinus & $\begin{array}{l}\text { ERV } 1 \\
\text { ERV } 2 \\
\text { ERV } 3 \\
\end{array}$ & $\begin{array}{l}0.7 \pm 0.09 \\
0.73 \pm 0.09 \\
0.81 \pm 0.1\end{array}$ & $\begin{array}{l}1.05 \pm 0.17 \\
1.25 \pm 0.13 \\
1.19 \pm 0.12\end{array}$ & $\begin{array}{l}0.72 \pm 0.1 \\
0.84 \pm 0.09 \\
0.96 \pm 0.11\end{array}$ & $\begin{array}{l}1.33 \pm 0.24 \\
1.16 \pm 0.14 \\
1.34 \pm 0.15\end{array}$ \\
\hline Larix and Pseudotsuga & $\begin{array}{l}\text { ERV } 1 \\
\text { ERV } 2 \\
\text { ERV } 3\end{array}$ & $\begin{array}{l}1.24 \pm 0.26 \\
1.89 \pm 0.29 \\
2.62 \pm 0.35\end{array}$ & $\begin{array}{l}1.49 \pm 0.3 \\
2.04 \pm 0.29 \\
1.55 \pm 0.32\end{array}$ & $\begin{array}{l}1.3 \pm 0.27 \\
1.41 \pm 0.28 \\
1.89 \pm 0.35\end{array}$ & $\begin{array}{l}1.71 \pm 0.3 \\
1.89 \pm 0.31 \\
1.74 \pm 0.34\end{array}$ \\
\hline Picea & $\begin{array}{l}\text { ERV } 1 \\
\text { ERV } 2 \\
\text { ERV } 3 \\
\end{array}$ & $\begin{array}{l}0.18 \pm 0.02 \\
0.15 \pm 0.04 \\
0.2 \pm 0.04\end{array}$ & $\begin{array}{l}0.27 \pm 0.07 \\
0.24 \pm 0.04 \\
0.28 \pm 0.05\end{array}$ & $\begin{array}{l}0.16 \pm 0.03 \\
0.2 \pm 0.04 \\
0.22 \pm 0.04\end{array}$ & $\begin{array}{l}0.24 \pm 0.04 \\
0.22 \pm 0.04 \\
0.23 \pm 0.04\end{array}$ \\
\hline Populus & $\begin{array}{l}\text { ERV } 1 \\
\text { ERV } 2 \\
\text { ERV } 3 \\
\end{array}$ & $\begin{array}{l}0.88 \pm 0.34 \\
0.51 \pm 0.23 \\
0.39 \pm 0.19\end{array}$ & $\begin{array}{l}0.61 \pm 0.27 \\
0.47 \pm 0.22 \\
0.47 \pm 0.22 \\
\end{array}$ & $\begin{array}{l}0.84 \pm 0.35 \\
0.47 \pm 0.22 \\
0.52 \pm 0.24\end{array}$ & $\begin{array}{l}0.98 \pm 0.42 \\
0.55 \pm 0.26 \\
0.42 \pm 0.21\end{array}$ \\
\hline Quercus & $\begin{array}{l}\text { ERV } 1 \\
\text { ERV } 2 \\
\text { ERV } 3\end{array}$ & $\begin{array}{l}0.28 \pm 0.07 \\
0.32 \pm 0.05 \\
0.38 \pm 0.04\end{array}$ & $\begin{array}{l}0.4 \pm 0.06 \\
0.36 \pm 0.03 \\
0.38 \pm 0.03\end{array}$ & $\begin{array}{l}0.45 \pm 0.03 \\
0.34 \pm 0.05 \\
0.44 \pm 0.05\end{array}$ & $\begin{array}{l}0.41 \pm 0.04 \\
0.33 \pm 0.05 \\
0.39 \pm 0.05\end{array}$ \\
\hline Tilia cordata & $\begin{array}{l}\text { ERV } 1 \\
\text { ERV } 2 \\
\text { ERV } 3 \\
\end{array}$ & $\begin{array}{l}0.21 \pm 0.05 \\
0.18 \pm 0.03 \\
0.22 \pm 0.04\end{array}$ & $\begin{array}{l}0.2 \pm 0.06 \\
0.22 \pm 0.04 \\
0.26 \pm 0.04\end{array}$ & $\begin{array}{l}0.28 \pm 0.04 \\
0.22 \pm 0.04 \\
0.26 \pm 0.05\end{array}$ & $\begin{array}{l}0.28 \pm 0.05 \\
0.26 \pm 0.04 \\
0.28 \pm 0.05\end{array}$ \\
\hline Avena-type & $\begin{array}{l}\text { ERV } 1 \\
\text { ERV } 2 \\
\text { ERV } 3 \\
\end{array}$ & $\begin{array}{l}2.38 \pm 2.03 \\
0.01 \pm 1.42 \\
0.004 \pm 2\end{array}$ & $\begin{array}{l}0.24 \pm 1.35 \\
0.002 \pm 1.36 \\
0.01 \pm 1.89\end{array}$ & $\begin{array}{l}2.03 \pm 2.18 \\
0.04 \pm 1.47 \\
0.02 \pm 2.14\end{array}$ & $\begin{array}{l}2.17 \pm 2.66 \\
0.01 \pm 1.48 \\
0.07 \pm 2.05\end{array}$ \\
\hline Hordeum-type & $\begin{array}{l}\text { ERV } 1 \\
\text { ERV } 2 \\
\text { ERV } 3 \\
\end{array}$ & $\begin{array}{l}1.87 \pm 0.33 \\
1.16 \pm 0.25 \\
2 \pm 0.4\end{array}$ & $\begin{array}{l}1.51 \pm 0.31 \\
1.13 \pm 0.23 \\
1.59 \pm 0.34 \\
\end{array}$ & $\begin{array}{l}1.63 \pm 0.33 \\
1.11 \pm 0.24 \\
1.95 \pm 0.41 \\
\end{array}$ & $\begin{array}{l}2.18 \pm 0.48 \\
1.17 \pm 0.25 \\
1.78 \pm 0.38 \\
\end{array}$ \\
\hline Secale & $\begin{array}{l}\text { ERV } 1 \\
\text { ERV } 2 \\
\text { ERV } 3 \\
\end{array}$ & $\begin{array}{l}1.1 \pm 0.15 \\
0.57 \pm 0.12 \\
0.47 \pm 0.17\end{array}$ & $\begin{array}{l}1.22 \pm 0.2 \\
0.38 \pm 0.1 \\
0.72 \pm 0.17 \\
\end{array}$ & $\begin{array}{l}1.22 \pm 0.19 \\
0.41 \pm 0.11 \\
0.81 \pm 0.2 \\
\end{array}$ & $\begin{array}{l}1.17 \pm 0.21 \\
0.56 \pm 0.12 \\
0.82 \pm 0.19\end{array}$ \\
\hline Triticum-type & $\begin{array}{l}\text { ERV } 1 \\
\text { ERV } 2 \\
\text { ERV } 3\end{array}$ & $\begin{array}{l}0.72 \pm 0.24 \\
0.08 \pm 0.18 \\
0.13 \pm 0.27\end{array}$ & $\begin{array}{l}0.78 \pm 0.26 \\
0.11 \pm 0.17 \\
0.08 \pm 0.26\end{array}$ & $\begin{array}{l}0.85 \pm 0.29 \\
0.09 \pm 0.18 \\
0.23 \pm 0.31\end{array}$ & $\begin{array}{l}0.8 \pm 0.31 \\
0.19 \pm 0.2 \\
0.23 \pm 0.29\end{array}$ \\
\hline Wild herbs & $\begin{array}{l}\text { ERV } 1 \\
\text { ERV } 2 \\
\text { ERV } 3\end{array}$ & $\begin{array}{l}0.05 \pm 0.01 \\
0.14 \pm 0.01 \\
0.01 \pm 0.01\end{array}$ & $\begin{array}{l}0.04 \pm 0.01 \\
0.12 \pm 0.01 \\
0.01 \pm 0.01\end{array}$ & $\begin{array}{l}0.05 \pm 0.003 \\
0.1 \pm 0.01 \\
0.01 \pm 0.01\end{array}$ & $\begin{array}{l}0.04 \pm 0.004 \\
0.13 \pm 0.01 \\
0 \pm 0.01\end{array}$ \\
\hline
\end{tabular}

where the relationship is determined by a few sites at which the tree often occurs in the understory. Similarly, Fagus shows different values depending on the inclusion of understory trees, while for Quercus a large difference is only seen for ERV submodel 1. PPEs for Carpinus, Fagus, and Quercus increase as their cover abundances are reduced, which is to be expected as fewer trees account for the same proportion of pollen. As the reduction in cover abundance is least for Alnus and Betula in the different datasets, their relative abundance increases slightly and 
there is a decreasing trend in the calculated PPEs for most ERV submodels when understory and/or young trees are excluded. For some species the direction of change varies between ERV submodels. For example Larix/Pseudotsuga PPEs decrease in submodel 3 and for Populus in submodels 1 and 2 .

\section{Discussion}

Flowering age and forest structure

The results show that flowering age and forest structures have a marked influence on the calculation of PPEs for some taxa. The autecology of the different tree species is modulating this effect in different ways and, based on the forest inventory data from Brandenburg, we can identify three different groups. Betula and Alnus are fast growing and reach their flowering age quickly. Thus, consideration of flowering age and understory have little influence on the estimates of their abundance, while their relative PPEs may be affected due to the reduction in effective abundance of other species. A second group consists of fast growing trees that are rarely found in the understory, while their flowering age may directly affect the pollen-vegetation relationship. In this dataset, examples of this type are Fraxinus and Picea. For the third group, mainly Fagus and Carpinus, the abundance in the understory has a larger effect than the flowering age on the pollen-vegetation relationship. These different ways in which the autecology of the tree species influences their pollen-vegetation relationship would also play a role in the natural woodlands of the past that we are aiming to reconstruct. However, nearly all European forests today are heavily managed and naturally occurring age structures are likely to be skewed towards younger non-flowering trees. The harvesting age of trees is often the time when they have started to produce ample pollen and thus the strong pollen producers are removed from the forest. Thus present tree plantations and woodlands may not be good analogies for the past, and it would be preferable to estimate relative pollen productivity from flowering trees only. Regional differences in the age structure of woodlands are a potential reason for differences in PPEs between regions in previous studies, e.g. those compared by Broström et al. (2008). However, omitting trees based on their flowering age is also not without problems, as trees start to flower at different ages depending on biotic and abiotic conditions (Schütt et al. 2006). Most trees will not go from not flowering to abundant pollen production in a single year, but rather gradually increase the amount of pollen produced with age. It is also likely that a free-standing tree produces more pollen than one that grows within a dense stand (Aaby 1994).
This effect of increased pollen production with forest openings has so far not been quantified, but, if important, it would greatly hamper our ability to reconstruct small openings in the forest using pollen data.

The occurrence of species in different stories in the canopy (e.g. superstructure, matured forest) is easy to assess in the field, but is difficult, if not impossible, to gauge from remote sensing. Tree abundance for PPEs has been estimated in a number of different ways: field estimates of basal area (e.g. Jackson and Kearsley 1998), cover of individual plants, considering different forest layers and leading to values above $100 \%$ (e.g. Soepboer et al. 2007), canopy cover as seen for one forest layer (e.g. Mazier et al. 2008) based on land-cover classifications in combination with field surveys and forest inventory, land-cover classification, and combinations with field surveys (e.g. Poska et al. 2011), remote sensing forest inventory data (Räsänen et al. 2007) or detailed forest inventory data (Theuerkauf et al. 2012 and present study).

Based on different assessments of heathland vegetation cover in western Norway, Bunting and Hjelle (2010) have shown that the way in which vegetation data are collected influences the PPEs and RSAP. We do not find differences in the RSAP, but show that PPEs are markedly influenced by the inclusion or exclusion of understory trees.

Considering the understory trees also has theoretical implications for the modeling of pollen dispersal. Tauber (1967) argued that the pollen carried to the lake through the trunk space is a significant component of the total pollen deposited at the site. However, this trunk space component is not considered in the dispersal models used here (Prentice 1985, 1988; Sugita 1993, 1994). In the present study, we omitted 10 lakes from the analysis that were situated in closed-canopy forest dominated by Fagus. The inclusion of this subset resulted in inflated PPEs for Fagus and less stable results for other taxa, indicating that the local abundance of Fagus around the lakes was not adequately considered in the model. The reason may be the dispersal model used in the ERV-program (Theuerkauf et al. 2012) and the large trunk space component of Fagus pollen in these situations. Sjögren et al. (2010) address the problem of the large trunk space component by dividing the pollen source area into different components and applying different dispersal functions. This approach seems rather ad hoc, as it is difficult to determine the contribution of the different components. However, this method can potentially accommodate a large trunk-space component (Filipova-Marinova et al. 2010). Pollen from understory trees may not contribute to above-canopy pollen transport in the same way as canopy trees, but it should be important in the trunk-space component (Tauber 1965). In this sense, the abundance of trees in the understory could be important near a site, while it may have little influence several 
hundred meters away from the site. Thus it could be meaningful to include the understory trees within a short distance around the site and exclude them from vegetation data further afield.

\section{RSAP}

The obtained RSAP of $7 \mathrm{~km}$ is rather large in comparison with similar analysis based on lakes of similar size, where RSAP values of $0.8-2 \mathrm{~km}$ were obtained (Nielsen and Sugita 2005; Soepboer et al. 2007; Hjelle and Sugita 2012; Poska et al. 2011). Poska et al. (2011) showed that vegetation classification can influence the RSAP for lakes, as was shown for moss polsters and heath vegetation by Bunting and Hjelle (2010). We did not find this effect using the different datasets with regards to flowering age and understory trees being omitted. The reason may be that the configuration of vegetation units remained the same in all situations and the omission of trees generally only affected their abundance rather than their presence. Hjelle and Sugita (2012) found that the distribution of lake-sizes could also influence the RSAP. The restricted dataset has a lakesize distribution nearing a normal distribution, which is slightly right skewed. The full dataset has a lake size distribution with a stronger skew to the right but yields a similar RSAP. It is most likely that the result is in fact due to the distribution of vegetation types and forest species in the study area, which is a well-known factor controlling the size of the RSAP (Sugita et al. 1999; Bunting et al. 2004; Nielsen and Sugita 2005; Hellman et al. 2009). Soil substrate, and therefore nutrient and water availability in north-east Germany are linked to the glacial geomorphology of the area. The Quaternary geology of the region consists of glacial sediments several hundred meters thick, including sands, clays and tills. The extensive outwash plains often only support Pinus trees and are rarely used for agriculture, while much of the nutrient-rich till plains are cleared for agricultural purposes. Nutrient-rich soils also developed on terminal moraines that are too steep for agriculture and are often covered by Fagus-dominated forests. These three geomorphological units dominate the landscape structure and vegetation-type patch size. They may occur in their pure form over tens of kilometres or mix with other geomorphological features creating smallerscaled vegetation patterns.

The lakes in Switzerland from which Soepboer et al. (2007) obtained an RSAP of $800 \mathrm{~m}$ were often surrounded by a belt of trees, and woodland patches in the surroundings have diameters of several hundred meters. The size of woodland patches in Estonia range from a few hundred meters to several kilometers and Poska et al. (2011) find a RSAP of 1,500-2,000 m. In Brandenburg extensive forests (which often stretch over more than $20 \mathrm{~km}$ ) alternate with extensive agricultural areas. Thus, extrapolation from the woodland patch-size versus RSAP in Switzerland and Estonia to the size of forest patches in Brandenburg may explain the large RSAP obtained. This example shows the dependency of RSAP on the patch size (Bunting et al. 2004; Hellman et al. 2009) for the selected lakes and indicates large effective patch size for the region investigated here.

\section{PPEs}

While the RSAP is markedly different from earlier studies the obtained relative PPEs agree with values obtained elsewhere (Fig. 7). The strong point of the analysis presented here is the forest inventory data, which are spatially and taxonomically precise. On the other hand the vegetation information extracted from the biotope map of Brandenburg is spatially precise but taxonomically vague. Agricultural lands are vast and, although we did use information on the proportion of different crops, we could not account for geographic differences between predominantly cereal and root crops, which exist in the area. Areas dominated by herbaceous vegetation were often distant from the sampling points so that long gradients could not be obtained, hampering the computation of PPEs. Our confidence in the obtained PPEs is high for arboreal pollen types, and for this reason we selected an arboreal taxon,

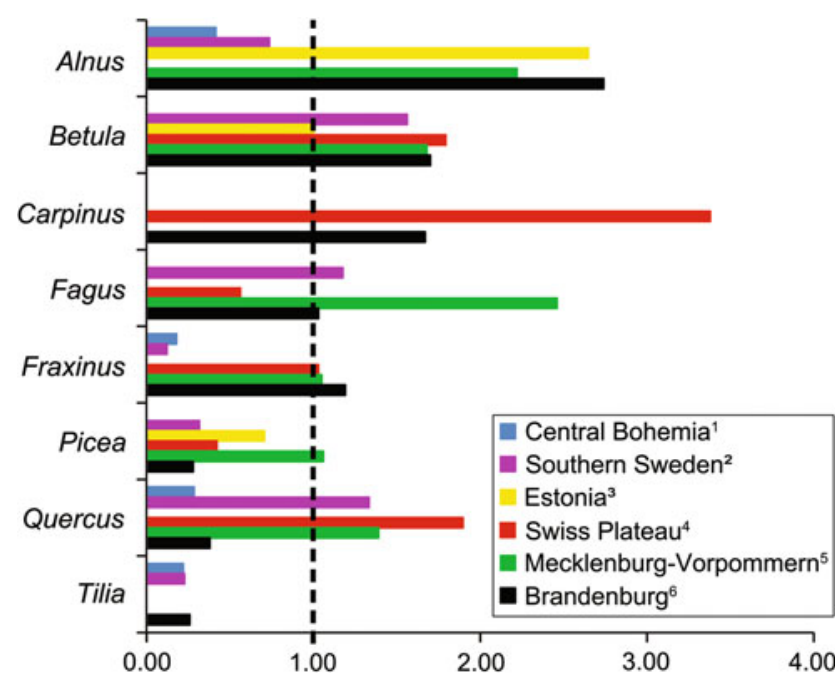

Fig. 7 PPEs for various taxa from different studies. The PPEs from Brandenburg are based on ERV 3 and on the dataset allFIDage. The PPEs from Sweden and Central Bohemia were calculated from moss polsters, the remaining studies were based on lake samples. All results were rescaled to assign a PPE of 1 (the dashed line) to the reference taxon Pinus. The comparison is based on original studies: 1 Abraham and Kozáková (2012); 2 Sugita et al. (1999) and Broström et al. (2004); 3 Poska et al. (2011); 4 Soepboer et al. (2007); 5 Theuerkauf et al. (2012); 6 this paper. PPE values of studies $2-4$ were taken from the overview by Broström et al. (2008) 
Pinus, as the reference taxon. We choose to report PPEs for herbaceous species as these differ widely between different study designs. The results presented here are based on a landscape perspective similar to the study by Poska et al. (2011) and may help evaluating published results or to design new studies. Our results indicate that the PPEs for Avena and Triticum-type are lower than for Secale and Hordeum-type, which could have implications for reconstructions of past cultural landscapes, although the exact values reported here have large uncertainties, as seen for example by the large differences between ERV submodels.

Our estimates for Alnus agree well with studies based on lakes (Poska et al. 2011), while studies using moss samples tend to produce much lower values (Southern Sweden, Broström et al. 2004; Central Bohemia, Abraham and Kozáková 2012). This may again be a result of the trunkspace component, which is generally not considered in the pollen dispersal model. Alnus is often found on the lake shore where a large amount of pollen may be carried in the trunk space, or simply drop into the lake, while moss samples from upland vegetation are generally distant from this tree species and thus collect Alnus pollen that is transported by the wind above the canopy. The good agreement for the PPE of Betula relative to Pinus between studies is encouraging, especially as Betula is often mixed in with other trees or occurs near the lake shore and it is thus difficult to estimate its abundance.

Few studies have obtained a PPE for Carpinus and our result agrees with Soepboer et al. (2007) in that its relative pollen production is higher than Pinus, although the relative amount differs greatly between the two studies. This may in part be due to the high uncertainty in the PPE for Pinus obtained for Switzerland (Soepboer et al. 2007). Our results show that the PPE of Carpinus depends strongly on whether understory trees are included in the vegetation estimate (Table 4), a factor which was not or only partly considered in several previous studies. More studies have estimated the PPE for Fagus with varying results. As discussed earlier, we suppose that the trunk-space transport of Fagus pollen may have a strong influence at sites within Fagus-dominated forest. This may contribute to the high PPE estimated by Theuerkauf et al. (2012) for the area just north of this study (calculated by the ERVv1.2.3. software). The value obtained here compares well with that estimated in southern Sweden, where, as in Brandenburg, both Pinus and Fagus are abundant forest trees. Also the PPE for Picea compares well to the estimate from southern Sweden, although the Picea trees in Brandenburg are planted and the distribution considered natural is situated just to the south of the study area. Larix and Pseudotsuga are planted widely in Brandenburg and were thus considered in the analysis. As the two trees cannot be differentiated by their pollen type, the PPE is difficult to interpret.
The values obtained for Quercus are surprisingly low and similar values have only been obtained from Central Bohemia (Abraham and Kozáková 2012). The dataset has a good spread of Quercus tree and pollen abundance, which gives us confidence in the results. In recent years many areas of Quercus trees in Brandenburg have been severely damaged by insects (particularly the moth Thaumetopoea processionea) and/or the fungus Microsphaera alphitoides (Möller et al. 2010) which can completely defoliate the tree, influencing its resource allocation and potentially reducing if not stopping the production of pollen. Also the age structure of Quercus in Brandenburg is skewed towards younger trees which may not produce the same amount of pollen as an abundance of older trees. While these factors would explain a somewhat lower PPE, the difference compared to the estimates from Switzerland is about threefold and thus difficult to explain by these factors alone.

The PPE for Tilia cordata compares well with the value for Tilia estimated in Southern Sweden (Sugita et al. 1999). Tilia cordata is the more abundant species in our dataset, while $T$. platyphyllos is also present. ERV model runs combining both pollen types and trees yield similar PPEs and thus we suggest that the value presented here may be appropriate for both species. However, T. platyphyllos is rare in the region and we thus restricted the final analysis to T. cordata.

It is desirable that the relationship between pollen and vegetation should be as good as possible for the reference taxon, because all the calculated PPEs depend on this taxon. We propose to use PPEs from ERV submodel 3 for vegetation reconstruction, because Pinus shows the best fit. Submodel 3 also produced lower likelihood function scores than the other submodels (Fig. 5), indicating a generally better fit to the data across all taxa. Based on the insights gained when working with the data, we recommend the further usage of the results from ERV submodel 3, based on the inclusion of all flowering trees, i.e. considering the effect of flowering age.

\section{Conclusion}

Both forest structure and flowering age have strong effects on the calculation of PPEs for most tree species, which should be considered when estimating PPEs or reconstructing vegetation. Forest structure is more important for slow growing trees like Fagus and Carpinus, while flowering age is most important for fast growing trees like Fraxinus and Picea, where flowering age is reached late. Based on this dataset, these effects may cause variations in PPEs in the order of up to $100 \%$ for trees that are slow growing and/or reach their flowering age late. 
Larger differences in PPEs between regions will most likely have different reasons, as will differences observed for trees that reach their flowering age early.

Trees growing at or near the lake shore contribute a large amount of pollen to the lake through the trunk-space component of pollen transport. This component is generally not considered when estimating PPEs, but could have a large effect and may thus be another factor explaining the differences between studies.

The large RSAP of $7 \mathrm{~km}$ is consistent with the landscape structure consisting of large units shaped by icemarginal processes during the last glaciation. The resulting differences in soil substrates and geomorphology are reflected in different land use today, and it would also have supported different forest types in the past.

This study adds to the growing dataset of PPEs for Europe and thus improves our ability to reconstruct past vegetation cover.

Acknowledgments We thank Ralf Köhler from the Landesumweltamt in Brandenburg for the authorization to do our fieldwork as well as Sabine Busch from Landesbetrieb Forst Brandenburg (LFB). We would like to thank Martin Theuerkauf for support in handling of the forest inventory data and long and good discussions. We thank Shinya Sugita for providing us with the unpublished software ERV-Analysis 1.2.3 and a critical discussion of the results. We also thank Jörg Christiansen for technical support. We thank the forest authorities of Brandenburg and Mecklenburg-Vorpommern for providing us with the forest data, particularly Konrad Müller from LFB, Potsdam. We also like to thank Simon Connor and an anonymous referee for helpful comments upon an earlier draft of this manuscript. This study was funded by the German Research Foundation (DFG, GI 732/1-1).

Open Access This article is distributed under the terms of the Creative Commons Attribution License which permits any use, distribution, and reproduction in any medium, provided the original author(s) and the source are credited.

\section{References}

Aaby B (1994) NAP percentages as an expression of cleared areas. Paläoklimaforschung 12:13-27

Abraham V, Kozáková R (2012) Relative pollen productivity estimates in the modern agricultural landscape of Central Bohemia (Czech Republic). Rev Palaeobot Palynol 179:1-12

Bennett KD, Willis KJ (2001) Pollen. In: Smol JP, Birks HJB, Last WM (eds) Tracking environmental change using lake sediments, vol 3., Terrestrial, algal and siliceous indicators. Kluwer, Dordrecht, pp 5-32

Beug H-J (2004) Leitfaden der Pollenbestimmung. Pfeil, München

Broström A, Sugita S, Gaillard MJ (2004) Pollen productivity estimates for reconstruction of past vegetation cover in the cultural landscape of southern Sweden. Holocene 14:371-384

Broström A, Nielsen B, Gaillard M-J, Hjelle K, Mazier F, Binney H, Bunting MJ, Fyfe R, Meltsov V, Poska A, Räsänen S, Soepboer W, Von Stedingk H, Suutari H, Sugita S (2008) Pollen productivity estimates of key European plant taxa for quantitative reconstruction of past vegetation: a review. Veget Hist Archaeobot 17:461-478
Bunting MJ, Hjelle KL (2010) Effect of vegetation data collection strategies on estimates of relevant source area of pollen (RSAP) and relative pollen productivity estimates (relative PPE) for nonarboreal taxa. Veget Hist Archaeobot 19:365-374

Bunting MJ, Middleton R (2005) Modelling pollen dispersal and deposition using HUMPOL software, including simulating windroses and irregular lakes. Rev Palaeobot Palynol 134:185-196

Bunting MJ, Gaillard M-J, Sugita S, Middleton R, Broström A (2004) Vegetation structure and pollen source area. Holocene 14: $651-660$

Bunting MJ, Armitage R, Binney HA, Waller M (2005) Estimates of "relative pollen productivity" and "relevant source area of pollen" for major tree taxa in two Norfolk (UK) woodlands. Holocene 15:459-465

Davis MB (1963) On the theory of pollen analysis. Am J Sci 261: $897-912$

Davis MB (2000) Palynology after Y2K-understanding the source area of pollen in sediments. Ann Rev Earth Planet Sci 28:1-18

Eisenhut G (1961) Untersuchung über die Morphologie und Ökologie der Pollenkörner heimischer und fremdländischer Waldbäume. Parey, Hamburg

Engel J (2010) Brandenburg-Kiefernland in Wandel. MILAktuell 2:29-30

Filipova-Marinova MV, Kvavadze EV, Connor SE, Sjögren P (2010) Estimating absolute pollen productivity for some European tertiary-relict taxa. Veget Hist Archaeobot 19:351-364

Gaillard MJ (2007) Pollen methods and studies-archaeological applications. In: Elias SA (ed) Encyclopedia of quaternary science, vol 3. Elsevier, Amsterdam, pp 2575-2595

Gaillard M-J, Sugita S, Bunting MJ, Middleton R, Broström A, Caseldine C, Giesecke T, Hellman SEV, Hicks S, Hjelle K, Langdon C, Nielsen AB, Poska A, Von Stedingk H, Veski S, POLLANDCAL Members (2008) The use of modelling and simulation approach in reconstructing past landscapes from fossil pollen data: a review and results from the POLLANDCAL network. Veget Hist Archaeobot 17:419-443

Gaillard M-J, Sugita S, Mazier F, Trondman A-K, Broström A, Hickler T, Kaplan JO, Kjellström E, Kokfelt U, Kuneš P, Lemmen C, Miller P, Olofsson J, Poska A, Rundgren M, Smith B, Strandberg G, Fyfe R, Nielsen AB, Alenius T, Balakauskas L, Barnekow L, Birks HJB, Bjune A, Björkman L, Giesecke T, Hjelle KL, Kalnina L, Kangur M, van der Knaap WO, Koff T, Lagerås $\mathrm{P}$, Latałowa $\mathrm{M}$, Leydet $\mathrm{M}$, Lechterbeck J, Lindbladh $\mathrm{M}$, Odgaard BV, Peglar S, Segerström U, Von Stedingk H, Seppä H (2010) Holocene land-cover reconstructions for studies on land cover-climate feedbacks. Clim Past 6:483-499

Giesecke T, Fontana SL (2008) Revisiting pollen accumulation rates from Swedish lake sediments. Holocene 18:293-305

Gregory PH (1973) The microbiology of the atmosphere. Leonard Hill, Aylesbury

Haller KE, Fickler H-H (1955) Waldbäume, Sträucher und Zwergholzgewächse. Winter, Heidelberg

Hellman S, Gaillard M-J, Bunting MJ, Mazier F (2009) Estimating the relevant source area of pollen in the past cultural landscapes of southern Sweden-a forward modelling approach. Rev Palaeobot Palynol 153:259-271

Hjelle KL (1998) Herb pollen representation in surface moss samples from mown meadows and pastures in western Norway. Veget Hist Archaeobot 7:79-96

Hjelle KL, Sugita S (2012) Estimating pollen productivity and relevant source area of pollen using lake sediments in Norway: how does lake size variation affect the estimates? Holocene 22:313-324

Jackson ST, Kearsley JB (1998) Quantitative representation of local forest composition in forest-floor pollen assemblages. J Ecol $86: 474-490$ 
Liedtke H, Marcinek J (2002) Physische Geographie Deutschlands. Klett-Perthes, Gotha

Linke C, Grimmert S, Hartmann I, Reinhardt K (2010) Auswertung regionaler Klimamodelle für das Land Brandenburg. Fachbeiträge des Landesumweltamtes Heft Nr. 113. http://www. mugv.brandenburg.de/cms/media.php/lbm1.a.2334.de/i_fb113. pdf. Accessed 27 February 2012

Mazier F, Brostöm A, Gaillard MJ, Sugita S, Vittoz P, Buttler A (2008) Pollen productivity estimates and relevant source area of pollen for selected plant taxa in a pasture woodland landscape of the Jura Mountains (Switzerland). Veget Hist Archaeobot 17: 479-495

Miller PA, Giesecke T, Hickler T, Bradshaw RHW, Smith B, Seppä H, Valdes PJ, Sykes MT (2008) Exploring climatic and biotic controls on Holocene vegetation change in Fennoscandia. J Ecol 96:247-259

MLUV (2009) Agrarbericht 2009 zur Land- und Ernährungswirtschaft des Landes Brandenburg. Ministerium für Ländliche Entwicklung, Umwelt und Verbraucherschutz des Landes Brandenburg (MLUV). Landesamt für Verbraucherschutz, Landwirtschaft und Flurneuordnung. http://www.mil.brandenburg.de/ sixcms/media.php/4055/Agrarbericht_2009.pdf. Accessed 27 February 2012

Möller K, Heydeck P, Hielscher K, Engelmann A, Wenk M, Schulz P-M, Dahms C, Born B, Dietz H, Braunschweig A (2010) Waldschutzbericht 2010. Jahresbericht der Hauptstelle für Waldschutz. Landeskompetenzzentrum Forst Eberswalde. http://forst.brandenburg.de/sixcms/media.php/4055/ws2010.pdf. Accessed 07 March 2012

Moore PD, Webb JA, Collinson ME (1991) Pollen analysis. Blackwell Scientific, Oxford

Nielsen AB (2004) Modelling pollen sedimentation in Danish lakes at c. A.D. 1800: an attempt to validate the POLLSCAPE model. J Biogeogr 31:1693-1709

Nielsen AB, Sugita S (2005) Estimating relevant source area of pollen for small Danish lakes around AD 1800. Holocene 15: $1006-1020$

Nielsen AB, Giesecke T, Theuerkauf M, Feeser I, Behre K-E, Beug H-J, Chen S-H, Christiansen J, Dörfler W, Endtmann E, Jahns S, De Klerk P, Kühl N, Latałowa M, Odgaard BV, Rasmussen P, Stockholm JR, Voigt R, Wiethold J, Wolters S (2012) Quantitative reconstructions of changes in regional openness in northcentral Europe reveal new insights into old questions. Quat Sci Rev 47:131-149

Pardoe HS, Giesecke T, Van der Knaap WO, Svitavska-Svobodova H, Kvavadze EV, Panajiotidis S, Gerasimidis A, Pidek IA, Zimny M, Swieta-Musznicka J, Latalowa M, Noryskiewicz AM, Bozilova E, Tonkov S, Filipova-Marinova MV, Van Leeuwen JFN, Kalnina L (2010) Comparing pollen spectra from modified Tauber traps and moss samples: examples from a selection of woodlands across Europe. Veget Hist Archaeobot 19:271-283

Parsons RW, Prentice IC (1981) Statistical approaches to R-values and pollen-vegetation relationship. Rev Palaeobot Palynol 32: $127-152$

Poska A, Meltsov V, Sugita S, Vassiljev J (2011) Relative pollen productivity estimates of major anemophilous taxa and relevant source area of pollen in a cultural landscape of the hemi-boreal forest zone (Estonia). Rev Palaeobot Palynol 167:30-39

Prentice IC (1985) Pollen representation, source area, and basin size: toward a unified theory of pollen analysis. Quat Res 23:76-86
Prentice IC (1988) Records of vegetation in time and space: the principles of pollen analysis. In: Huntley B, Webb TIII (eds) Vegetation history. Kluwer, Dordrecht, pp 17-42

Prentice IC, Parsons RW (1983) Maximum likelihood linear calibration of pollen spectra in terms of forest composition. Biometrics 39:1051-1057

Räsänen S, Suutari H, Nielsen AB (2007) A step further towards quantitative reconstruction of past vegetation in Fennoscandian boreal forests: pollen productivity estimates for six dominant taxa. Rev Palaeobot Palynol 146:208-220

Renberg I (1991) The HON-Kajak sediment corer. J Paleolimnol 6: $167-170$

Rispens JA (2003) Der Nadelbaumtypus-Schritte zu einem imaginativen Baumverständnis. Elemente der Naturwissenschaft 79: $51-77$

Schröck O (1949) Die Vererbung der Frühblüte der Kiefer. Der Züchter 19:247-254

Schütt P, Weisgerber H, Schuck H-J, Lang U, Stimm B, Roloff A (2006) Enzyklopädie der Laubbäume. Nikol, Hamburg

Sjögren P, Connor SE, Van der Knaap WO (2010) The development of composite pollen-dispersal functions for estimating absolute pollen productivity in the Swiss Alps. Veget Hist Archaeobot 19:341-349

Soepboer W, Sugita S, Lotter AF, Van Leuwen JFN, Van der Knaap WO (2007) Pollen productivity estimates for quantitative reconstruction of vegetation cover on the Swiss Plateau. Holocene 17:1-13

Stinglwagner G, Haseder I, Erlbeck R (2005) Das Kosmos Wald- und Forstlexikon. Kosmos, Stuttgart

Sugita S (1993) A model of pollen source area for an entire lake surface. Quat Res 39:239-244

Sugita S (1994) Pollen representation of vegetation in quaternary sediments: theory and method in patchy vegetation. J Ecol 82: 881-897

Sugita S (2007a) Theory of quantitative reconstruction of vegetation I: pollen from large sites REVEALS regional vegetation composition. Holocene 17:229-241

Sugita S (2007b) Theory of quantitative reconstruction of vegetation II: all you need is LOVE. Holocene 17:243-257

Sugita S, Gaillard MJ, Broström A (1999) Landscape openness and pollen records: a simulation approach. Holocene 9:409-421

Sugita S, Hicks S, Sormunen H (2010) Absolute pollen productivity and pollen-vegetation relationships in northern Finland. J Quat Sci 25:724-736

Tauber H (1965) Differential pollen dispersion and the interpretation of pollen diagrams. Danmarks Geologiske Undersøgelse. II Række 89:1-69

Tauber H (1967) Investigations of the mode of pollen transfer in forested areas. Rev Palaeobot Palynol 3:277-286

Theuerkauf M, Kuparinen A, Joosten H (2012) Pollen productivity estimates strongly depend on assumed pollen dispersal. Holocene. doi:10.1177/0959683612450194

Umweltbundesamt, DLR-DFD (2004) CORINE Land Cover 2000. Daten zur Bodenbedeckung - Deutschland. http://www.corine. dfd.dlr.de

Von Stedingk H, Fyfe R, Allard A (2008) Pollen productivity estimates from the forest-tundra ecotone in west-central Sweden: implications for vegetation reconstruction at the limits of the boreal forest. Holocene 18:323-332 